\title{
Mangrove sedimentary characteristics and implications for crab Ucides cordatus (Crustacea, Decapoda, Ucididae) distribution in an estuarine area of the Amazonian region
}

\author{
José Diego GOMES ${ }^{1}$, Fernando Araújo ABRUNHOSA², Darlan de Jesus de Brito SIMITH³, \\ Nils Edvin ASP2*
}

\begin{abstract}
At the coastal zone sediments, water and organisms interact intensely. At equatorial tidal-dominated coast mangroves are abundant. These areas are well-known for their ecological importance. Considering the mangroves of Atlantic South America, the mangrove crab, Ucides cordatus has ecological and economic prominence. High densities of this crab are found on the Amazon coast. This study investigates the sediment distribution of the Bragança mangrove area (Amazon coast, Brazil) and its correlations with vegetation and mangrove crab distribution. Sediments of 47 sites, as well as crabs from sites with different sediment and vegetation, were sampled. Results show that surface sediment of the area is mainly composed by silt (59\%), with $21 \%$ sand and $20 \%$ clay. Variations in sorting and skewness are the product of local variations in clay and sand content. The vegetation type was significantly correlated to mangrove crab characteristics, abundance and weight/size. Sediment characteristics are also substantially different according to the vegetation type. Areas where Avicennia germinans prevails have more sand and clay than areas of Rizophora mangle, in which silt is dominant and crabs were significantly heavier. The present results have showed that the distribution of sediments, crabs and vegetation at mangrove areas are strongly correlated. Thus, they should be studied in conjunction.
\end{abstract}

KEYWORDS: coastal plain, sediment distribution, tides, vegetation, North Brazil, mangrove crab

\section{Características sedimentares de manguezal e implicações para a distribuição do caranguejo-uçá Ucides cordatus (Crustacea, Decapoda, Ucididae) em uma área estuarina amazônica}

\begin{abstract}
RESUMO
$\mathrm{Na}$ zona costeira, sedimentos, água e organismos interagem intensamente. Nas costas equatoriais dominadas por maré os manguezais são abundantes. Estas áreas são conhecidas por sua importância ecológica. No caso dos manguezais da costa atlântica da América do Sul o caranguejo-uçá Ucides cordatus (Linnaeus, 1763) se destaca por sua relevância ecológica e econômica, sendo que altas densidades deste organismo são encontradas na zona costeira amazônica. O presente estudo investiga a distribuiçáo de sedimentos nos manguezais de Bragança (costa Amazônica, Brasil) e suas correlaçôes com a vegetação e a distribuiçáo do caranguejo-uçá. Quarenta e sete amostras de sedimento foram avaliadas, assim como caranguejos de 8 destas áreas foram coletados, onde o tipo dominante de vegetação foi também identificado. Os resultados demonstram que os sedimentos superficiais, assim como no extrato 0,8 a $1 \mathrm{~m}$ de profundidade, na área são principalmente compostos por silte (59\%), incluindo em média $21 \%$ de areia e $20 \%$ de argila. O tipo de vegetaçáo predominante foi significativamente correlacionado com a abundância e tamanho/peso dos caranguejos. As características sedimentares também foram substancialmente diferentes dependendo da vegetaçáo. Áreas dominadas por Avicennia germinans tiveram mais areia e argila que as áreas dominadas por Rizophora mangle, onde a fração silte prevalece grandemente e os caranguejos eram significativamente maiores e mais abundantes. Os resultados demonstraram que sedimentos, invertebrados bentônicos e vegetação estão intimamente relacionados nos manguezais e devem ser estudados de maneira integrada.
\end{abstract}

PALAVRAS-CHAVE: planície costeira, distribuição de sedimentos, maré, vegetação, norte do Brasil, caranguejo de mangue.

${ }^{1}$ Faculdade de Engenharia de Pesca - Universidade Federal do Pará (FEPESCA-UFPA); Campus Bragança: Alameda Leandro Ribeiro, s/n - Bairro Aldeia - Bragança, PA - Brazil CEP: 68600-000; Tel: 5591 3425-1593; E-mail: jdiegogv@hotmail.com.

2 Instituto de Estudos Costeiros - Universidade Federal do Pará (IECOS-UFPA); Campus Bragança: Alameda Leandro Ribeiro, s/n - Bairro Aldeia - Bragança, PA - Brazil - CEP 68600-000; Tel: 5591 3425-1593; *: autor correspondente, E-mail: nilsasp@ufpa.br.

3 Programa de Pós-graduação em Biologia Ambiental - Universidade Federal do Pará (PPGBA-UFPA); Campus Bragança: Alameda Leandro Ribeiro, s/n - Bairro Aldeia - Bragança, PA - Brazil - CEP: 68600-000; Tel: 5591 3425-1593; *: autor correspondente, E-mail: simithdjb@hotmail.com. 


\section{INTRODUCTION}

Tides, waves and associated currents are the main drive forces for sediment transport and geomorphology of softsediment coasts around the world. Where tides prevail, estuaries and tidal flats are the most conspicuous sedimentary environments. If these tide-dominated areas present adequate (warm) climate, sedimentation and nutrients, mangroves rapidly cover the tidal flats and estuarine borders.

These areas are well-known for their high productivity, low diversity and general ecological importance, such as reproduction and nursing of vertebrate and invertebrate species, including several of economic relevance. Considering the Atlantic coast of the American continent, the mangrove crab, Ucides cordatus (Linnaeus, 1763), has an ecological and an economic prominence. It is a typical mangrove resident and occurs from Florida at the United States to Santa Catarina in southern Brazil (Melo 1996, Tavares 2003). High densities of that species are found in the Amazonian coast, northern Brazil (Castro 1986, Nordi et al. 2009).

The northern sector of the Brazilian coast is dominated by tides and by the Amazon River, with a catchment area of more than $6 \times 10^{6} \mathrm{~km}^{2}$, a maximum water discharge in the order of $200 \times 10^{3} \mathrm{~m}^{3} \mathrm{~s}^{-1}$ and suspended sediment load in the order of $3.5 \times 10^{6}$ ton day ${ }^{-1}$ (Meade et al. 1985). The interaction of tides, mud supply and equatorial climate result in substantial mangrove development and the referred important mangrove crab occurrence. There, the climate is controlled mainly by seasonal changes in the position of the Inter-tropical Convergence Zone (ITCZ), which stays in latitudes around $14^{\circ} \mathrm{N}$ during August and September, migrating southwards until around $2^{\circ} \mathrm{S}$ during March and April, exactly over the Amazon region (Souza Filho et al. 2009). Therefore, the region experiences high precipitation in the first months of the year, with $73 \%$ of the total rainfall from January to April, while September, October and November are especially dry months (Moraes et al. 2005). The annual regional rain fall is high, contributing for estuarine development, ranging from 2,300 to $2,800 \mathrm{~mm}$ (Moraes et al. 2005), where the rainiest month is usually March, and the driest month is usually October.

The described general setting of the area results in 7,600 $\mathrm{km}^{2}$ of continuous mangrove forests (Souza Filho and Paradella 2003, Souza Filho 2005), including an extremely irregular and jagged coastline, harboring 23 estuaries (Souza Filho et al. 2009). The estuarine embayments are sand dominated, intercalated by the protruding of muddy dominated coastal plains, usually covered by mangroves. The sediment dynamics between the estuarine basins and muddy plains are interrelated and the coast line is continuously changing (Souza Filho et al. 2009).
At that area, the Bragança coastal plain is found, which is in average $8 \mathrm{~km}$ wide and $25 \mathrm{~km}$ long, mainly covered by mangrove forest and separating Taperaçu and Caeté estuaries (Figure 1), where the U. cordatus corresponds up to $84 \%$ of the benthic biomass (Fernandes 1997, Koch and Wolf 2002). It is being intensely captured by the local population, although its occurrence is locally not yet substantially affected by the economic catchment (Diele 2000, Glaser and Diele 2004, Diele et al. 2005). Besides, impacts of crab catchment were not focused in the present study.

Despite its relevance, the relationships of mangrove crab distribution and ecology with sediment and vegetation distribution is complex and the number of studies involving this theme increased just in the late years (Nordhaus et al.

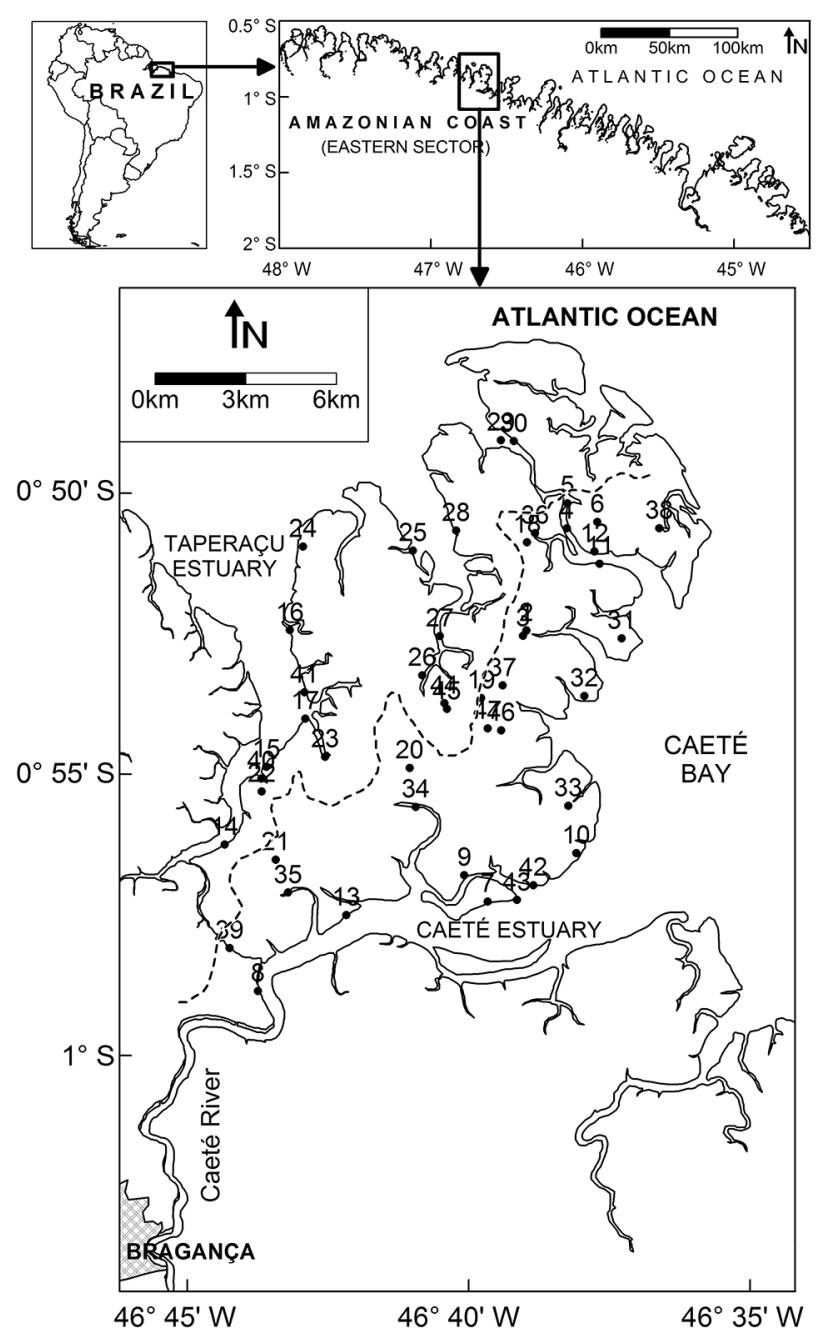

Figure 1 - Location of the study area (Bragança coastal plain), including the sampling sites. The dashed line indicates the area division in two estuarine sides, according to the ebbing and flooding pattern. 
2006, Diele and Simith 2006). Depending on the coastal morphodynamics and the geological setting, substantial sediment distribution differences are observed along the mangroves, where the type of prevailing mangrove species (e.g. Rizophora mangle and Avicennia germinans) is also related with the sedimentary characteristics (Mehlig 2001). Depending on the sand/mud and organic contents, a type of vegetation may prevail and both, sediment and vegetation coverage, have impacts on crabs distribution and ecology, due to, for instance, the availability of food and burrowing easiness (Nordhaus et al. 2006). Furthermore, crab distribution is also affected by mangrove leaf litter load and decomposition, which is also variable depending on the prevailing mangrove tree species (see Amouroux and Tavares 2005).

On the other hand, sediment deposition and its granulometric variation is strongly correlated with the tide hydrodynamics, especially regarding current velocity and frequency of inundation, which also affects mangrove trees settling and growth (Dittmar 1999). Therefore, a correlation between sediment distribution and crabs abundance and size/ weight is expected. For instance, there seems to be a tendency for $A$. germinans to establish itself more successfully in slightly elevated areas (frequently sandier than lower areas), whereas $R$. mangle prevails in more frequently inundated locations with soft, muddy sediments (Mehlig 2001).

In this context, the present work investigates the superficial sediment characteristics of the Bragança mangrove area (Amazon coast, Brazil - Figure 1) and its correlations with vegetation coverage, as well as, the implications for the mangrove crab distribution and ecology.

\section{MATERIALS AND METHODS}

In order to evaluate the characteristics of the superficial sediment distribution at the mangroves of the Bragança coastal plain, as well as its implications to mangrove crab distribution and correlations with vegetation coverage, sediments and crabs were sampled, correlated and compared to the available vegetation coverage maps.

\section{Sampling}

Concerning the sediments, 47 points were sampled, comprising different parts of the mangrove, such as the margins of Caeté and Taperaçu estuaries, central parts of the peninsula, innermost and outermost mangrove areas (Figure 1). To avoid seasonal variation effects in both, crab and sediment characteristics, sediment samples and crabs were taken only during wet season (March to July) from 2008 to 2010.

Sampling sites were located using Global Positioning System (GPS), with the hand GPSmap CSx Garmin ${ }^{\mathrm{TM}}$, which provides a precision of few (e.g. 3 to 9) meters even under vegetation shade. All information was geographically disposed and compared using the software Surfer ${ }^{\mathrm{TM}}$ 8. The used interpolation method was the triangulation with linear interpolation, including $200 \mathrm{~m}$ of grid spacing. The interpolation method was chosen because of its high fidelity to the original values.

Sediment samples were taken with a shovel, which collected approx. $1 \mathrm{~kg}$ of soil from the upper $10 \mathrm{~cm}$. At 8 selected sites (40 to 47 - Figure 1) crabs were also caught, where 10 squares of $4 \mathrm{~m}^{2}$ were sampled and all specimens found in these areas were caught. The sampling squares were disposed along a $100 \mathrm{~m}$ line, where their positions were chosen randomly, as proposed by Alcântara Filho (1978) and already successfully applied in Amazonian mangroves (Fernandes and Carvalho 2007). Furthermore, all collected specimens were measured (weight, carapace width and length) and the sex was also determined.

\section{Vegetation distribution}

The evaluation of vegetation coverage and prevailing species at the mangrove area of Bragança was performed by Mehlig (2001), based on the combination of satellite imagery and field observations and phytosociological studies. Since comparisons of sediment and crab distribution between areas of different vegetation were intended, sites for crab catch were chosen based on that mangrove vegetation mapping (Mehlig 2001 ), where the prevailing vegetation type was verified on the field, during the sediment and crab sampling.

\section{Sediment processing and data analysis}

Sediment samples were submitted to organic matter and grain size analysis. They were processed according to the methodology described by Suguio (1973), consisting firstly in the removal of salt from samples, followed by the removal and measurement of organic matter content $(\% \mathrm{OM})$ by oxidation with $\mathrm{H}_{2} \mathrm{O}_{2}$. Then, samples were submitted to wet sieving to separate fine $(<62.5 \mu \mathrm{m})$ and coarse sediments. The dried

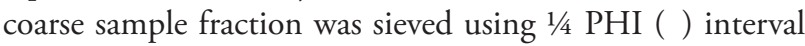
and the fine sediments were evaluated based on the settling velocities. Granulometric distribution and statistic parameters were calculated according to Folk and Ward (1957), based on the logarithm grain size scale Phi, as proposed by Wentworth (1922), where the grain size Phi corresponds to the negative two-based logarithm of the grain size in millimeter. Further, the spatial variation of sediments was analyzed.

In order to compare the differences between biological traits of crabs (e.g. carapace length: CL, carapace width: CW and wet weight) and different types of vegetation (Rizophora mangle: RM, and Avicennia germinans: AG), the biological samples were analyzed in the laboratory. The differences in crab characteristics in relation to sediment and vegetation coverage were then analyzed through a non-parametric test 
(Mann-Whitney U-test), where crab biometric data (CL, CW and weight) and sediments from $R$. mangle and A. germinans sampling sites were compared. Significant differences were then considered when $\mathrm{p}<0.05$ (95\% of confidence of interval).

In order to statistically correlate sedimentology and crab biometry, a 'BEST' (Biota and/or Environment Matching) was also performed using the software Primer', where the used resemblance measure was Euclidian Distance, with rank correlation method of Spearman, using the BIOENV method. The percentage of sand, silt and clay were correlated with crab weight, carapace width and length.

Further comparisons considering the peninsula side of sampling (west/Taperaçu; east/Caeté) were also performed, since sediment analyses have shown lateral differences. In order to divide the peninsula in two sides, satellite imagery was used (Landsat TM of $1^{\text {st }}$ Aug/2001; Aster of $23^{\text {th }}$ Nov/2003; and CBERS of $3^{\text {rd }} \mathrm{Aug} / 2005$ ). All images are RGB compositions, with original spatial resolutions of 30,15 and
$20 \mathrm{~m}$, respectively. Based on the drainage of tidal channels and creeks, a divisor line was established. The satellite images, as the sediment distribution, were georeferred and plotted using the Surfer ${ }^{\circledR}$ v.8 software.

\section{RESULTS}

\section{Sediment characteristics and variation}

From all 47 collected samples, only one was classified as Sandy (very fine sand), and 6 samples were classified as Clayey. Most of samples (40) were classified as Silty. The average of all samples reveals contents of $20 \%$ sand, $59 \%$ silt and $21 \%$ clay. Mean organic matter content was 5.5\%. At 8 disperse sites along the area sediment samples were also taken at 0.8 to $1 \mathrm{~m}$ depth, beside surficial samples. Granulometric analysis did not show substantial differences between superficial and the deeper samples. Therefore, sampling and analysis involve basically superficial samples, which are also strongly related to settling of the different mangrove trees. Figure 2 presents an

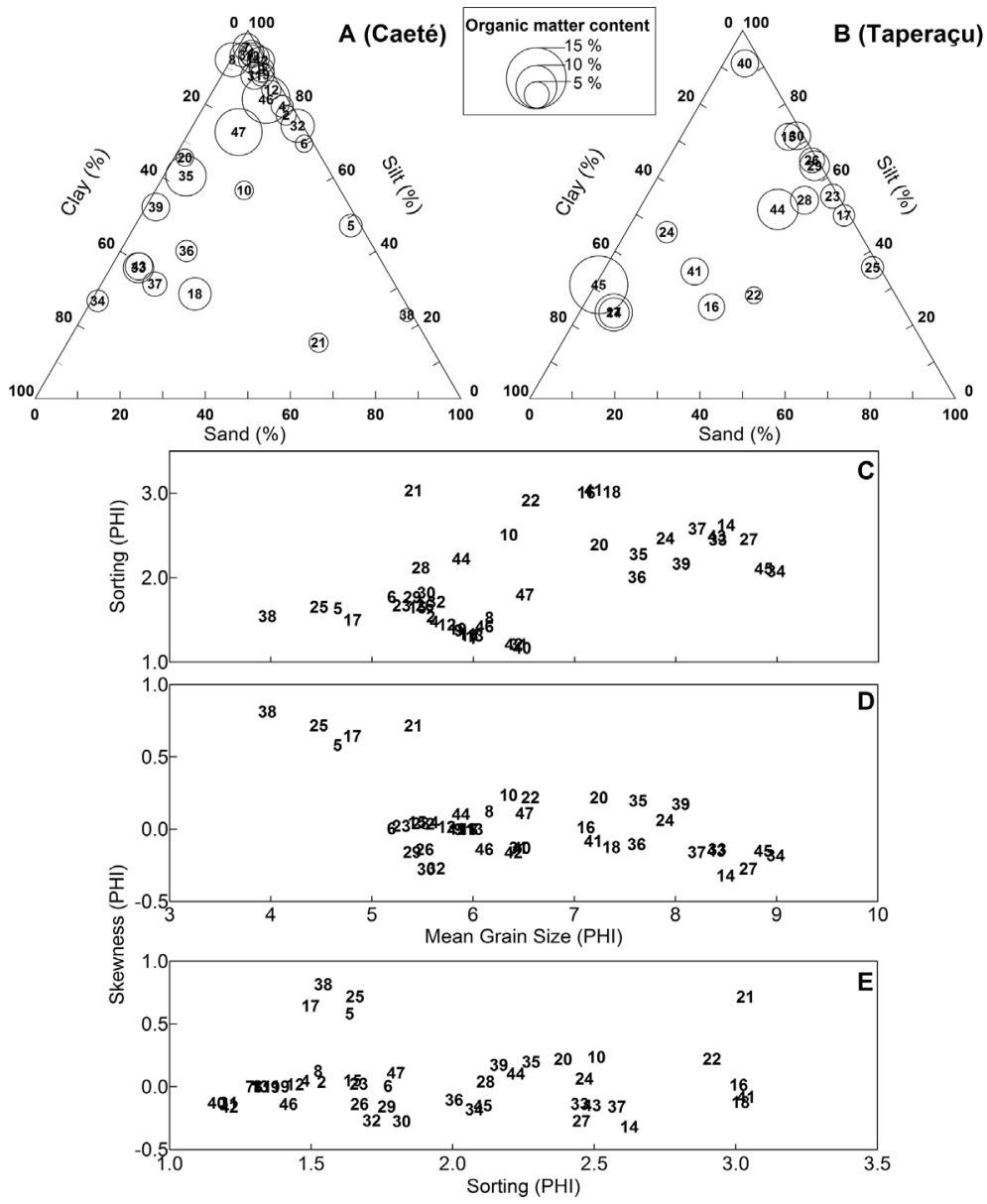

Figure 2 - Overview of superficial sediment characteristics at the Bragança mangroves. A (Caeté side) and B (Taperaçu side): Ternary diagrams of sand/silt/ clay fractions, where the circles correspond to organic matter content; C, D and E: Dispersion diagrams correlating skewness, sorting and mean grain size. 
overview of the granulometric characteristics and variations among the samples.

Considering the statistical analysis of grain size distribution, the overall mean grain size was $6.44 \mathrm{Phi}$, ranging from 3.97 to 8.99 Phi. Most of the samples were classified as not wellsorted. Approx. the half of samples presented a symmetric distribution. One quarter showed negative skewness (coarser grains surplus) and other quarter presented positive asymmetric distribution ('excess' of finer grains). This pattern is the result of variations in sand and clay content in essentially silty samples.

To evaluate the variations in mean grain size, sorting and skewness of sediments along the Bragança mangrove, so-called dispersion diagrams (Suguio 1973) were built (Figure 2, C, $\mathrm{D}$ and $\mathrm{E})$. However, no significant grouping was observed.

Maps of sediment distribution including sand, silt and clay fractions were performed and showed the differences in the sediment coverage of the west/Taperaçu side and the east/Caeté side, despite local variations (Figure 3). It can be observed that sediments at the west/Taperaçu side are sandier, whereas the sediments at the east/Caeté side are siltier, as suggested by the ternary diagrams on Figure 2. The clay fraction is overall frequent and locally abundant, but there is no a clear pattern of distribution.

In relation to the prevailing vegetation type, the t-test was applied to correlate sedimentological and vegetation variations, but these were significant $(\mathbb{Q}=0.05)$ only for silt ( $\mathrm{t}$-test $=6.555, \mathrm{p}<0.001)$, where silt content is significantly higher at Avicennia areas.

\section{Crab biometry and sediment - vegetation correlations}

A total of 111 specimens of the mangrove crab Ucides cordatus were caught in the study area. The sampled individuals were then grouped according to the type of vegetation and estuary (Caeté and Taperaçu). In the Caeté estuary, a total of 44 crabs $(68.2 \%$ males and $31.8 \%$ females) were collected in the Rhizophora mangle area (RM) and only 13 specimens (92.3\% males and 7.7\%) in the Avicennia germinans area (AG). In the Taperaçu estuary were caught 36 individuals (50\% males and 50\% females; RM) and 18 crabs $(72.2 \%$ males and $27.8 \%$ females; $A G)$.

In the Caeté estuary, the carapace length (CL) of the crabs sampled in RM ranged from 46 to $78 \mathrm{~mm}$ and from those specimens caught in AG had the carapace length varying from 44 to $68 \mathrm{~mm}$. The carapace width (CW) showed values ranging from 30 to $61 \mathrm{~mm}$ (RM) and from 35 to $59 \mathrm{~mm}$ (AG). The wet weight of the sampled crabs in RM ranged from 38.0 to $219.2 \mathrm{~g}$ and in $\mathrm{AG}$ it varied from 39.0 to 133.0 g. No significant differences $(\mathrm{p}>0.05)$ were found between the average values of $\mathrm{CL}$ and $\mathrm{CW}$, and wet weight of the sampled crabs between the two different types of vegetation (RM and AG) (Figure 4).

In the Taperaçu estuary, the crabs collected in RM showed a CL ranging between 50 and $74 \mathrm{~mm}$ and those individuals caught in AG presented values varying between 45 and 66 $\mathrm{mm}$. The CW varied from 38 to $75 \mathrm{~mm}$ in RM and from 34 to $48 \mathrm{~mm}$ in AG. The weight of the sampled specimens ranged between 50.2 and $165.2 \mathrm{~g}$ in RM and between 39.7
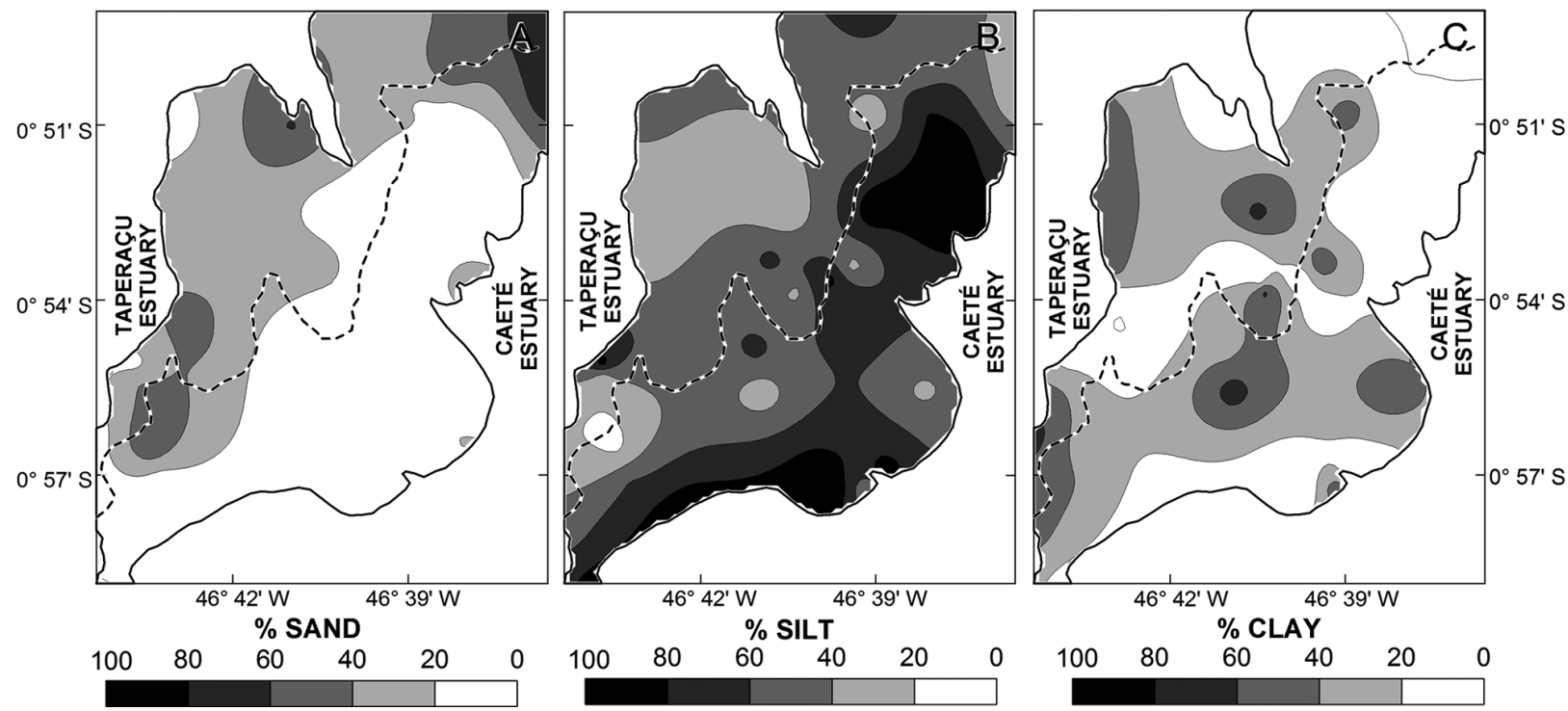

Figure 3 - Maps of sediment distribution, including sand (A), silt (B) and clay (C) fractions. The outer black line, encompassing the contour maps, represents the border of the coastal plain, whereas the dashed line indicates the area division in two estuarine sides, as showed in Figure 1. 

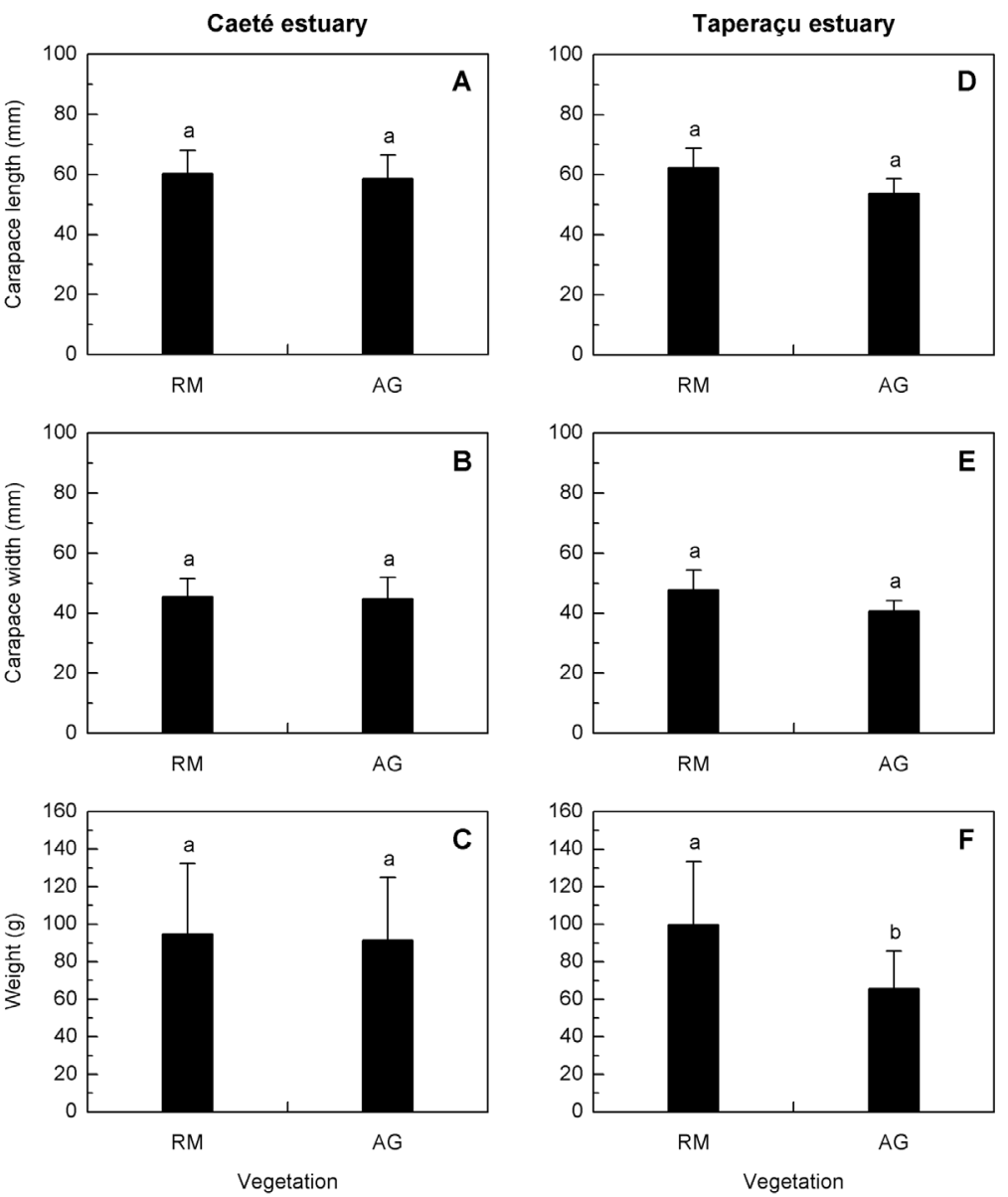

Figure 4 - Carapace length and width (mm, average \pm standard deviation) and wet weight ( $\mathrm{g}$, average \pm standard deviation) of the sampled crabs in the respective mangrove areas (Rhizophora mangle: RM; Avicennia germinans: AG) belonging to the Caeté and Taperaçu estuary.

and $126.8 \mathrm{~g}$ in AG. The average body size (CL and CW) of the collected crabs did not present significant differences $(\mathrm{p}$ $>0.05$ ) between the respective types of vegetation (Figure 4). However, concerning to the average weight of the crabs, a significant difference was found between the two respective sampled areas (Figure 4). The specimens collected in RM showed the highest average wet weight $(99.7 \pm 33.6 \mathrm{~g})$.

Further, the so-called BEST test also showed a moderate, but significant, correlation of weight with granulometric characteristics of the sediment, corresponding to a correlation value of 0.432 . The correlation with carapace width or length was substantially lower. Therefore, it indicates that the prevailing of RM is correlated with sediment granulometric characteristics, as well as the prevailing of RM results in heavier crabs.

Figure 5 shows the sediment fractions and organic matter contents, as well as the crabs biometric information and female percentage, which are compared according to the prevailing vegetation and side of the peninsula. As other comparisons have showed, differences in crab dimensions and weight, as well as sediment characteristics, are substantial in relation to the vegetation prevailing type. Important (but not statistically significant) differences are observed comparing the sides of peninsula, but they do not result in measurable differences in crab characteristics.

\section{DISCUSSION}

In a preliminary analysis the sediment distribution of each sample is the product of very local conditions, such as proximity to tidal creeks and very local vegetation variation. Thus, eventual correlations of samples according to type of prevailing vegetation or general location (e.g. east/Caeté versus west/Taperaçu side) are partially hidden by local influence. The absence of a clear pattern of distribution of the clay fraction reflects the influence of such local factors.

Nevertheless, the abundance of sand at the Taperaçu/west side, in relation to the siltier Caetéleast side could be associated with morphodynamic differences on the Taperaçu and Caeté estuaries. At Taperaçu a catchment area, and therefore continental sediment supply, is almost inexistent (Asp et al. 

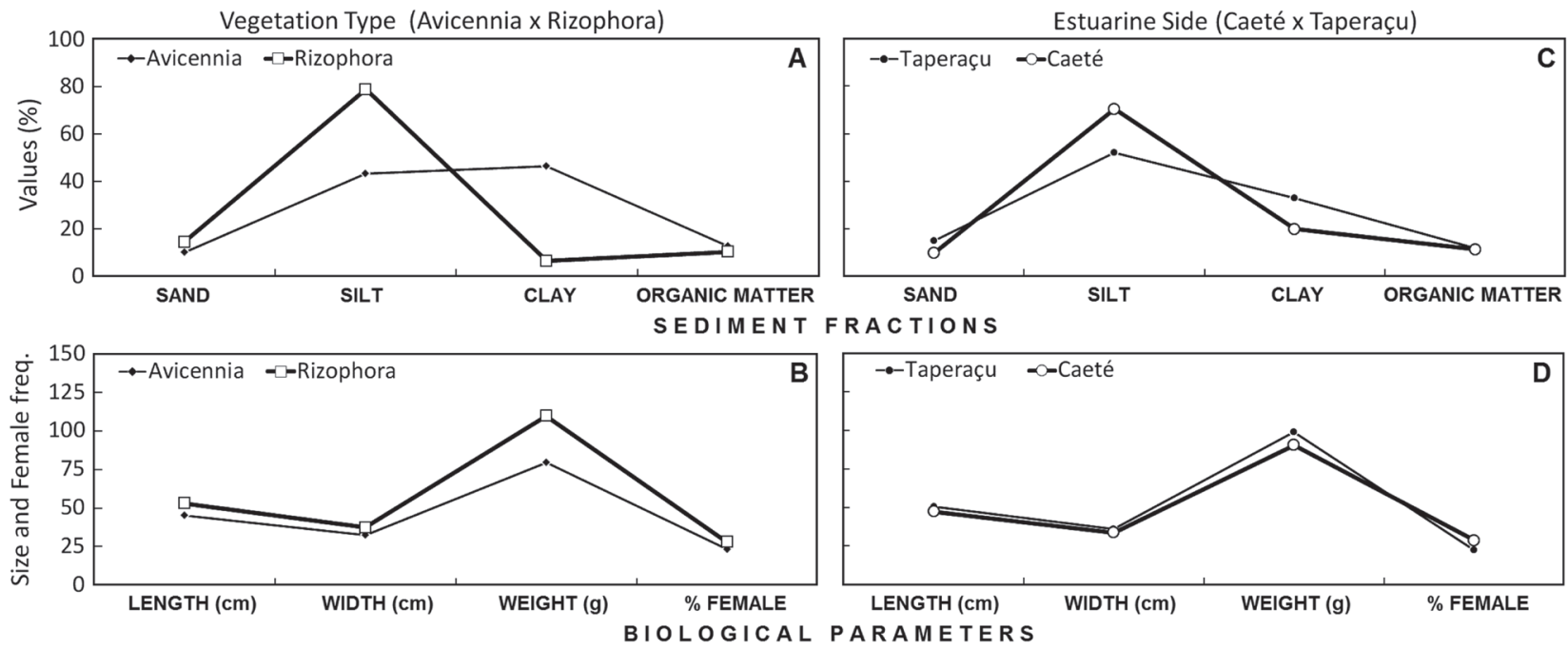

Figure $\mathbf{5}$ - Comparison of sediment distribution and crab biometry according to the prevailing vegetation type (Rizophora or Avicennia) and estuarine side of collection (Taperaçu or Caeté side).

2012), while Caeté eastuary has a catchment area of approx. $1,550 \mathrm{~km}^{2}$ and the higher silt contents observed at this side might by of continental origin (Souza Filho et al. 2009).

Regarding to the evaluated specimen of Ucides cordatus, the respective biometric values found in the present study correspond to the sexual maturity for the species, according to Pinheiro and Fiscarelli (2001), but are inferior of the minimum allowed size for economic catchment, according to Brazilian laws. These results were expected, since the crab catchment within this study was not selective regarding size, in opposition to the exploitation. In the $R$. mangle area in the Taperaçu estuary, the crabs were significantly heavier and more abundant. These results are in agreement with a previous study (Fernandes and Carvalho 2007) and would be directly related with the availability of food and its specific biochemical composition (Nordhaus et al. 2006).

The differences observed in sediments suggest that Rizophora occupy more silty areas, whereas Avicennia occupies slightly sandier areas, as also suggested by Mehlig (2001). On the other hand, as Avicennia occupies an area, the clay deposition seems to increase due to the presence of pneumatophores. The areas showing higher concentrations of clay (Figure 3) usually present Avicennia dominance.

Furthermore, crab distribution (Ucides included) is also affected by mangrove leaf litter load and decomposition, showing a preference for Rizophora as food source (Amouroux and Tavares 2005, Nordhaus et al. 2006). Thus, the correlation of crab and sediment distribution might be even indirect, but substantial.

Furthermore, it can be summarized that the superficial sediment distribution of the mangrove peninsula of Bragança is mainly composed by silt, especially at the east/Caeté side.
Overall sediment proportion of main fractions is $59 \%$ for silt, $21 \%$ for sand and $20 \%$ for clay. The sediment distribution is the product, in first instance, of the general morphodynamics, and both corroborate for the prevailing of a mangrove tree (e.g. Rizophora mangle or Avicennia germinans). If samples are compared individually, vegetation seems to be a remarkable factor in determining the mangrove crab characteristics, especially abundance and weight.

If the whole area is considered, differences in sediment due to morphodynamic differences of the estuaries bordering the peninsula are relevant, therefore it was observed that the west/Taperaçu side is sandier, and the east/Caeté side is siltier. However, these differences are not resulting in substantial differences in the crabs' biometric values.

Sediment characteristics are also substantially different comparing areas of different types of prevailing vegetation, but their interaction is complex. Although, results showed a significant correlation of sediment characteristics, crab weight and prevailing of Rizophora mangle.

The present results have showed that the distribution of sediments, crabs and vegetation at mangrove areas are strongly correlated, especially in estuaries and tidal plains with important mangrove development, as here studied. Thus, sediments, vegetation and crabs should be studied in conjunction.

\section{ACKNOWLEDGEMENTS}

The authors would like to thank the Conselho Nacional para Desenvolvimento Cientifico e Tecnológico of Brazil (CNPq) for the funding of the project, as well as for the scholarship of José Diego Gomes (PIBIC) and the fellowship of Nils E. Asp (501014/2009-8). We are also thankful to all personal 
of the Laboratório de Geologia Costeira (LAGECO) of the Universidade Federal do Pará (UFPA), for the assistance at the fieldwork and laboratorial analyses. The authors are also thankful to the reviewers for their valuable contributions to this manuscript.

\section{REFERENCES}

Alcântara-Filho, P. 1978. Contribuição ao conhecimento da biologia do caranguejo-uçá, Ucides cordatus (Linaeus, 1763) (Crustacea, Decapoda, Brachyura) no manguezal do Rio Ceará (Brasil). Arquivos de Ciência do Mar, 18: 1-14.

Amouroux, J.M.; Tavares, M. 2005. Natural recovery of Amazonian mangrove forest as revealed by Brachyuran crab fauna: preliminary description. Vie et Milieu-Life and Environment, 55: 71-79.

Asp, N.E.; Schettini, C.A.F.; Siegle, E.; Silva, M.S.; Brito, R.N.R. 2012. The Dynamics of a Frictionally-dominated Amazonian Estuary. Brazilian Journal of Oceanography (in press).

Castro, A.C.L. 1986. Aspectos bioecológicos do caranguejo-uçá Ucides cordatus (Linnaeus, 1763), no Estuário do Rio dos Cachorros e Estreito do Coqueiro, São Luis, MA. Boletim do Laboratório de Hidrobiologia, 7: 7-26.

Diele, K. 2000. Life history and population structure of the exploited mangrove crab Ucides cordatus (L) (Decapoda: Brachyura) in the Caeté estuary, North Brazil. Zentrum Für Marine Tropenökologie - Contribution, 9: 1-103.

Diele, K.; Koch, V.; Saint-Paul, U. 2005. Population structure and catch composition of the exploited mangrove crab Ucides cordatus in the Caeté estuary, North Brazil: Indications of overfishing? Aquatic Living Resources, 18: 169-178.

Diele, K.; Simith, D. 2006. Salinity tolerance of northern Brazilian mangrove crab larvae, Ucides cordatus (Ocypodidae): Necessity for larval export? Estuarine, Coastal and Shelf Science, 68: 600608.

Dittmar, T. 1999. Outwelling of Organic Matter and Nutrients from a Mangrove in North Brazil: Evidence from Organic Tracers and Flux Measurements. Zentrum Für Marine Tropenökologie Contribution, 5: 1-93.

Fernandes, M.E.B. 1997. The ecology and productivity of mangroves in the Amazon region, Brazil. PhD Thesis, York University, York, England. 214 p.

Fernandes, M.E.B.; Carvalho, M.L. 2007. Bioecologia de Ucides cordatus Linnaeus, 1763 (Decapoda: Brachyura) na costa do Estado do Amapá. Boletim do Laboratório de Hidrobiologia, 20: $15-22$.

Folk, R.L.; Ward, W.C. 1957. Brazos river bar: a study in the significance of grain size parameters. Journal of Sedimentary Petrology, 27: 3-26.

Glaser, M.; Diele, K. 2004. Asymmetric Outcomes: Assessing the biological economic and social sustainability of a mangrove crab fishery, Ucides cordatus (Ocypodidae), in North Brazil. Ecological Economics, 49: 361-373.
Koch, V.; Wolff, M. 2002. Energy budget and ecological role of mangrove epibenthos in the Caeté estuary, North Brazil. Marine Ecology Progress Series, 228: 119-130.

Meade, R.H.; Dunne, T.; Richey, J.E.; Santos, U.M.; Salati, E. 1985. Storage and remobilization of suspended sediment in the lower Amazon River of Brazil. Science, 228: 488-490.

Mehlig, U. 2001. Aspects of tree primary production in an equatorial mangrove forest in Brazil. Zentrum Für Marine Tropenökologie - Contribution, 14: 1-155.

Melo, G.A.S. 1996. Manual de Identificação dos Brachyura (Caranguejos e Siris) do Litoral Brasileiro. Editora Plêiade/FAPESP, São Paulo, SP, Brasil. 604 p.

Moraes, B.C.; Costa, J.M.N.; Costa, A.C.L.; Costa, M.H. 2005. Variação espacial e temporal da precipitação no estado do Pará. Acta Amazonica, 35: 207-214.

Nordhaus, I.; Wolff, M.; Diele, K. 2006. Litter processing and population food intake of the mangrove crab Ucides cordatus in a high intertidal forest in northern Brazil. Estuarine, Coastal and Shelf Science, 67: 239-250.

Nordi, N.; Nishida, A.K.; Alves, R.R.N. 2009. Effectiveness of two gathering techniques for Ucides cordatus in Northeast Brazil: implications for the sustainability of mangrove ecosystems. Human Ecology, 37: 121-127.

Pinheiro, M.A.A.; Fiscarelli, A.G. 2001. Manual de Apoio à Fiscalização do Caranguejo-Uçá (Ucides cordatus). UNESP / CEPSUL / IBAMA. 43 p.

Souza Filho, P.W.M.; Paradella, W.R. 2003. Use of synthetic aperture radar for recognition of Coastal Geomorphological Features, land-use assessment and shoreline changes in Bragança coast, Pará, Northern Brazil. Anais da Academia Brasileira de Ciências, 75: 341-356.

Souza Filho, P.W.M. 2005. Costa de Manguezais de Macromaré da Amazônia: Cenários Morfológicos, Mapeamento e Quantificação a partir de Dados de Sensores Remotos. Revista Brasileira de Geofisica, 23: 427-435.

Souza Filho, P.W.M.; Lessa, G.C.; Cohen, M.C.L.; Costa, F.R.; Lara, R.J. 2009. The Subsiding Macrotidal Barrier Estuarine System of the Eastern Amazon Coast, Northern Brazil, p. 347-376. In: Dillenburg, S.F.; Hesp, P.A. (Eds.). Geology and Geomorphology of Holocene Coastal Barriers of Brazil. Lecture Notes in Earth Sciences, v.107. Springer-Verlag, New York, USA.

Suguio, K. 1973. Introdução à Sedimentologia. Edgard Blücher Ltda./ EDUSP, São Paulo, SP. 317 p.

Tavares, M. 2003. True Crabs, p. 327-352. In: Fischer, W. (Ed.). FAO species identification sheets for fishery purposes: Western Central Atlantic (Fishing Area 31). FAO, Rome.

Wentworth, C.K. 1922. A scale of grade and class terms for clastic sediments. Journal of Geology, 30: 377-392.

Aceito em:12/04/2012

Recebido em:06/10/2012 